\title{
Immobilization of Yeast Pichia stipitis for Ethanol Production
}

*Sang-Eun Lee ${ }^{1 \dagger}$, Ji-Eun Lee ${ }^{1 \dagger}$, Eun-Jin $\mathrm{Kim}^{1+}$, Joon Ho Choi ${ }^{2}$, Woon Yong Choi ${ }^{3}$, Do Hyung Kang ${ }^{4}$, Hyeon-Yong Lee ${ }^{3}$ and Kyung-Hwan Jung ${ }^{1}$ *

${ }^{1}$ Department of Biotechnology, Chungiu National University, Jeungpyung 368-701, Korea

${ }^{2}$ Department of Food Science and Biotechnology, Wonkwang University, Iksan 570-749, Korea

${ }^{3}$ Division of Biomaterials Engineering, Kangwon National University, Chuncheon 200-701, Korea

${ }^{4}$ Korea Ocean Research \& Development Institute, Ansan 426-744, Korea

Received January 3, 2012 /Revised March 13, 2012 /Accepted March 13, 2012

\begin{abstract}
In this study, DEAE-cotton [derivatized by 2-(diethylamino)ethyl chloride hydrochloride (DEAE $\mathrm{HCl})$ ] was prepared as a carrier for immobilized Pichia stipitis for ethanol production. When cotton was derivatized with $0.5 \mathrm{M} \mathrm{DEAE} \cdot \mathrm{HCl}$, the yeast cell suspension was adsorbed at $100 \%$ of the initial cell $\mathrm{OD}_{600}$. The adsorbed yeast cells were estimated to be $101.8 \mathrm{mg}$-dry cells/g-DEAE-cotton. In particular, when a flask culture using the immobilized yeast cells was conducted in a glucose and xylose-containing medium, the yeast cells on the DEAE-cotton gradually produced ethanol, according to glucose and xylose consumption; the ethanol yield was approximately 0.33 g-ethanol/g-monosaccharide. Because DEAE-cotton was successfully used as a carrier for ethanol production from a glucose and xylose-containing medium, we expect that this bioethanol production process may be used for the bioethanol production process from the hydrolysate of lignocellulosic biomass. All the results of DEAE-cotton were compared with those of DEAE-cellulose as a carrier for immobilization.
\end{abstract}

Key words : Cotton, DEAE $\mathrm{HCl}$ derivatization, yeast cell immobilization, ethanol production, Pichia stipitis

\section{서 론}

효모를 고정화하여 ethanol 생산에 이용하는 방법은 여러 문헌에서 보고되고 있으며, 효모 세포 고정화를 통하여 생산 성 향상과 같은 공정상의 여러가지 잇점을 얻을 수 있었다 [12-14,20,22]. 그리고, 이러한 고정화 효모 세포를 이용하는 다 양한 반응기 시스템이 연구되어 왔으며[2,3,8-10,14,26], 특히, 경제성을 고려하여 세포의 흡착을 이용한 다양한 부산물 $[2,3,5,9,13,17,18,26]$ 이 세포 고정화를 위한 담체로서 관심을 끌 고 있다. 그 중에서 woodchips, sugarcane bagasse, sorghum bagasse, 그리고 corncob과 같은 agricultural byproducts가 특 히 이러한 경제성과 간편한 방법 때문에 많이 연구되어왔다.

그 동안 cotton은 세포 고정화 담체로서 보다는 분리/정제를 위한 담체로서 많이 사용되어져 왔다 $[4,6,7,15,19]$. 본 연구에서 는 이러한 선행연구결과를 바탕으로 2-(diethylamino)ethyl chloride hydrochloride [DEAE $\mathrm{HCl},\left(\mathrm{C}_{2} \mathrm{H}_{5}\right)_{2} \mathrm{NCH}_{2} \mathrm{CH}_{2} \mathrm{Cl} \cdot \mathrm{HCl}$ ] 으로 cotton (탈지면)을 derivatization하여 cellulose로 이루어 진 cotton을 효모 세포의 고정화 담체로서 사용하기 위한 연구 를 시도하였다. 즉, 효모의 세포 표면이 주로 negative charge

†These three authors contributed equally to this work and should be considered as equal first authors.

*Corresponding author

Tel : +82-43-820-5246, Fax : +82-43-820-5272

E-mail : khjung@cjnu.ac.ckr
를 가지는 것으로 알려져 있기 때문에[1], 효모와 cotton과의 흡착력을 증가시키기 위하여, 중성 $\mathrm{pH}$ 에서 positive charge를 가지는 ligand인 "DEAE-" $\mathrm{pK}=11.5)$ 를 가지도록 $\mathrm{DEAE} \cdot \mathrm{HCl}$ 을 처리하였다.

본 연구에서는 먼저 DEAE-cotton과 DEAE-cellulose에 효 모 세포를 흡착시키는 최적의 조건에 대하여 조사하였다. 그 리고, 최적의 조건에서 효모 세포를 흡착시킨 후, glucose와 xylose가 들어 있는 배지에 넣어 배양하여, 세포성장, 단당류 소비, 그리고 ethanol 생산 등에 대하여 조사하였다. 특히, cotton에 "DEAE-" 를 붙인 담체가 효모를 이용한 ethanol 생산용 담체로서 이용 가능하다는 것을 보여 주려고 하였으며, 그 성 능을 DEAE-cellulose와 비교하여 분석하였다. 본 연구에서 glucose와 xylose가 들어간 배지를 사용하여 흡착 고정화된 효모로 ethanol 생산을 연구한 이유는, 많은 lignocellulosic biomass의 가수분해물에는 육탄당인 glucose 뿐만 아니라 오탄 당인 xylose가 포함되어있기 때문이다. 즉, DEAE-cotton을 육 탄당과 오탄당이 포함된 가수분해물에서 ethanol을 생산하는 공정의 담체로 이용하기 위하여서였다.

\section{재료 및 방법}

\author{
시약 \\ 2-(Diethylamino)ethyl chloride hydrochloride (DEAE. \\ $\mathrm{HCl}$ ) 그리고 DEAE-cellulose는 각각 Acros (USA)와 Sigma-
}


Aldrich (USA) 것을 사용하였다. yeast extract와 peptone은 Becton Dickinson (USA) 것을 사용하였고, acetonitrile과 a -naphtol은 Daejung Chemical Co. (Korea)과 Sigma-Aldrich (USA) 제품을 사용하였다. 그 외의 시약들은 reagent-grade급 으로 사용하였다.

\section{효모}

본 연구에서는 육탄당과 오탄당을 이용하여 ethanol을 생 산할 수 있는 효모 Pichia stipitis (P. stipitis) CBS 7126을 사용하 였다.

\section{DEAE-Cotton 제조방법}

$250 \mathrm{ml}$ Erlenmeyer flask에 cotton (탈지면)과 $18 \% \mathrm{NaOH}$ 의 비율이 $1: 50(\mathrm{w}: \mathrm{v})$ 되게 넣고, $4^{\circ} \mathrm{C}$ 에서 overnight 동안 방치 한다. 그리고 $\mathrm{NaOH}$ 용액을 버린 후, cotton과 DEAE·HCl 용 액 비율이 1:50 (w:v) 되게 DEAE· $\mathrm{HCl}$ 용액을 넣고, 상온에서 정치된 상태로 1 시간 반응시켰다.

\section{$\mathrm{DEAE}-\mathrm{cotton}$ 에 효모 고정화}

$50 \mathrm{ml}$ conical tube에 DEAE-cotton과 증류수 혹은 YPDX 배지(yeast extract, $10 \mathrm{~g} / \mathrm{l}$; peptone, $20 \mathrm{~g} / \mathrm{l}$; glucose, $5 \mathrm{~g} / \mathrm{l}$; xylose, $2.5 \mathrm{~g} / \mathrm{l}$ )를 1:50 (w:v)의 비율로 넣고, 10분 동안 방치한 다. 그리고, DEAE-cotton을 건져내어 $50 \mathrm{ml}$ conical tube에 넣고, 여기에 $10 \mathrm{ml}$ 효모 현탁액을 넣는다. 그리고 나서 이것을 상온에서 shaking plate에 올려 놓고, 효모세포가 DEAE-cotton에 부착되도록 한다.

\section{DEAE-cellulose에 효모 고정화}

$50 \mathrm{ml}$ conical tube에서 DEAE-cellulose과 증류수 혹은 YPDX 배지를 1:50 (w:v)의 비율로 넣고, 10분 동안 방치한다. 그리고, 이 용액을 원심분리하여, 그 상등액을 버린 후, 여기에 효모 현탁액 $10 \mathrm{ml}$ 을 넣는다. 그리고 나서 이것을 상온에서 shaking plate에 올려 놓고, 효모세포가 DEAE-cellulose에 부 착되도록 한다.

\section{효모가 흡착 고정화된 DEAE-cotton를 이용한 flask culture}

DEAE-cotton의 경우, $250 \mathrm{ml}$ Erlenmeyer flask에 $0.4 \mathrm{~g}$ DEAE-cotton과 YPDX 배지에 넣고 10분 동안 방치한다. 그리 고, 배지를 제거한 후, 여기에 $\mathrm{OD}_{600}$ (optical density at 600 nm) 7.6 인 $10 \mathrm{ml}$ 효모 현탁액을 넣는다. 그리고, shaking incubator에 넣고, 효모 세포가 DEAE-cotton에 부착되도록 한 다. 완전히 효모 세포가 흡착된 것을 확인 한 후, 이것을 새로 운 $30 \mathrm{ml}$ YPDX 배지가 들어있는 $250 \mathrm{ml}$ Erlenmeyer flask에 넣고 배양을 시작한다. DEAE-cellulose의 경우, $250 \mathrm{ml}$ Erlenmeyer flask에 YPDX $15 \mathrm{ml}$ 과 DEAE-cellulose $2 \mathrm{~g}$ 을 넣
고 멸균한 후, $\mathrm{OD}_{600}$ 이 5.8 인 효모 현탁액 $15 \mathrm{ml}$ 을 넣는다. 그리 고 shaking incubator에 넣고, 효모 세포가 DEAE-cotton에 부 착되도록 한다. 완전히 효모 세포가 흡착된 것을 확인 한 후, 이를 원심분리로 회수하여, 새로운 $30 \mathrm{ml} \mathrm{YPDX}$ 배지가 들어 있는 $250 \mathrm{ml}$ Erlenmeyer flask에 넣고 배양을 시작한다. 두 경우 모두, shaking incubator $\left(30^{\circ} \mathrm{C}, 60 \mathrm{rpm}\right)$ 에서 배양을 실시 하였다.

\section{전자현미경}

효모가 고정화된 DEAE-cotton과 DEAE-cellulose를 증류수 로 씻은 후, $60^{\circ} \mathrm{C}$ 에서 24 시간 건조한다[5]. 그리고 scanning electron microscope (ESEM, FEI Quanta ${ }^{\mathrm{TM}}$ 400, The Netherlands)를 이용하여 관찰하였다.

\section{분석}

효모성장은 spectrophotometer (Spectronic, Thermo Scientific, USA)로 $600 \mathrm{~nm}$ 에서 optical density $\left(\mathrm{OD}_{600}\right)$ 를 측정 하여 monitoring하였으며, 배양액 중의 에탄올 함량은 gas chromatography (8610C, SRI, USA)를 이용하여 분석하였다. 이때 컬럼은 Chromosomb 101 [L=6 ft, ID=1/8 inch, 80/100 mesh, stainless steel tubing (Alltech, USA)]을 사용하였고, 자세한 운전 조건은 선행 논문에 설명하였다[23-25]. Glucose 와 xylose의 양은 thin-layer chromatography (TLC)를 이용하 여 분석하였으며, TLC plate (Partisil ${ }^{\circledR}$ K5F, Whatman)는 $20 \times 10 \mathrm{~cm}$ 로 잘라서 사용하였고, 시료는 $1 \mu 1$ 를 loading 하였으 며, 전개용매는 acetonitrile과 증류수를 85:15 비율로 혼합하여 사용하였다. 전개가 끝난 후, TLC plate를 발색시약 $(0.5 \%$ a -naphtol, $5 \% \mathrm{H}_{2} \mathrm{SO}_{4}$ in ethanol)에 담갔다 꺼낸 후, dry oven에 넣고 $80^{\circ} \mathrm{C}$ 에서 15 분간 말려서 발색시켰다. Glucose, isomaltodextrin와 maltodextrin이 TLC plate 상에서 나타내는 spot의 강도와 그들 농도와의 관계가 선형적으로 비례하였다 는 Robyt와 Mukerjea의 논문[15]에서의 이론을 근간으로 glucose와 xylose의 양은 TLC를 통하여 정량분석 하였으며, 이 때 단당류의 정량 분석을 위해서 단당류의 spot을 AlphaEase FC softwere (Alpha Innotech, USA)를 이용하여 일차원상의 peak로 전환한 후, 농도를 알고 있는 표준물질과 비교하여 단 당류의 함량을 계산하였다.

\section{결과 및 고찰}

\footnotetext{
DEAE-cotton과 DEAE-cellulose에 효모 세포 흡착 고 정화

Cotton을 효모 세포의 고정화 담체로 사용하기 위하여, cotton을 DEAE로 derivatization 시키는 최적조건에 대하여 연구 하였다. Fig. 1과 같이 여러가지 DEAE· $\mathrm{HCl}$ 농도(0.0-2.0 M)로 처리한 $0.1 \mathrm{~g}$ 의 DEAE-cotton에 효모 세포 $\left(\mathrm{OD}_{600}=2.9,5.0,7.1\right)$
} 

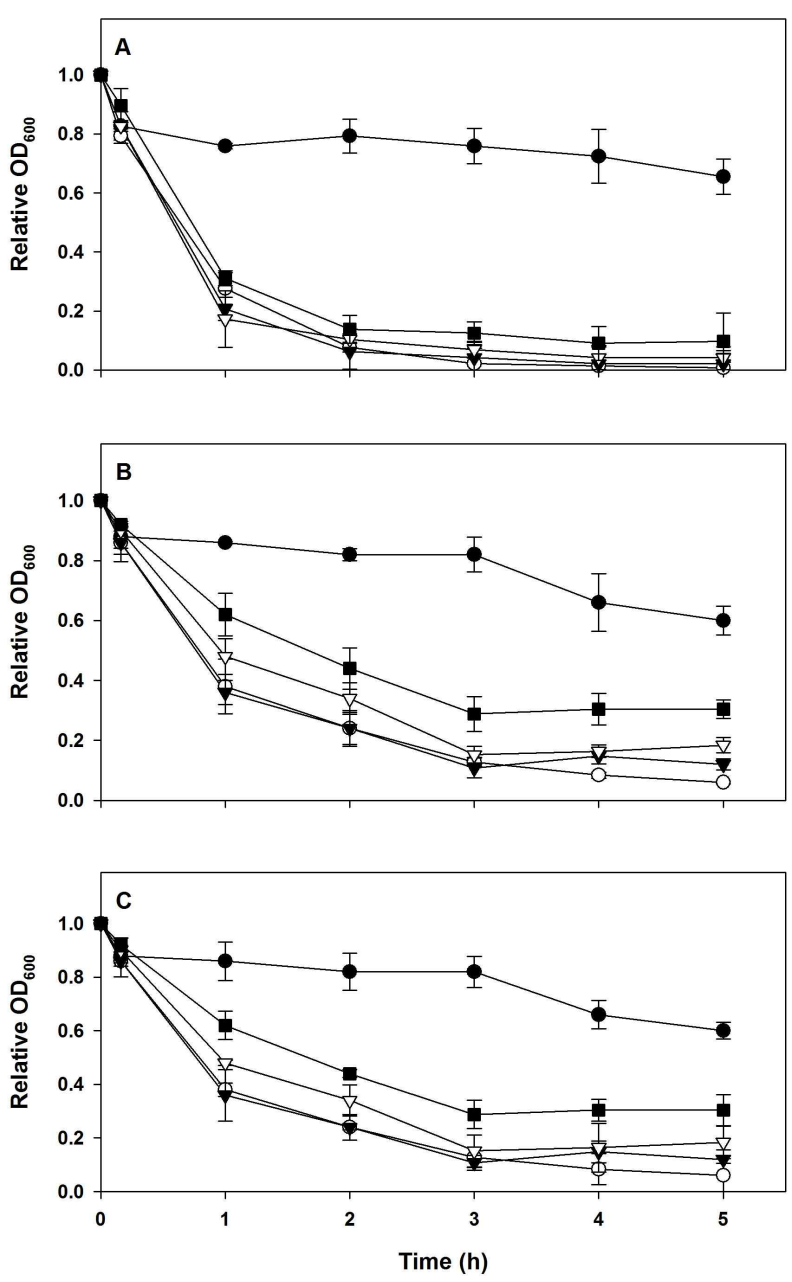

Fig. 1. Immobilizations of yeast cell on DEAE-cotton. DEAE-cotton of $0.1 \mathrm{~g}$ was added, and the initial yeast cell $\mathrm{OD}_{600}$ was (A) 2.9, (B) 5.0, and (C) 7.1, respectively. DEAE·HCl concentrations were $0.0(\mathbf{O}), 0.25(\bigcirc), 0.5(\boldsymbol{\nabla}), 1.0(\nabla)$, and $2.0 \mathrm{M}(\boldsymbol{\square})$, respectively. A $10 \mathrm{ml}$ yeast cell suspension was prepared in distilled water. Triplicate samples were used for the measurement, and the average and standard deviation were calculated.

를 흡착시켜 보았다. 그 결과 효모 세포 농도가 2.9일 경우에는 0.25 에서 $2.0 \mathrm{M} \mathrm{DEAE} \cdot \mathrm{HCl}$, 효모 세포 농도가 5.0 혹은 7.1일 경우에는 0.25 에서 $1.0 \mathrm{M}$ 의 DEAE·HCl로 cotton을 처리하였 을 때, 적어도 3시간 정도 효모세포를 흡착을 시키면, 약 $95 \%$ 이상의 세포가 세포농도와 관계없이 DEAE-cotton에 붙을 수 있음을 확인 하였다. 그러나 Fig. 1의 실험은 증류수에 효모 세포를 현탁시킨 환경에서 수행한 실험이었다. 효모 세포의 활성을 고정화 단계에서 좀 더 잘 유지하고, 배양환경으로 효 모 세포의 보다 빠른 적응을 위하여, Fig. 2와 같이 YPDX 배지 에서 DEAE-cotton과 효모 세포와의 흡착을 조사하였다. 이 때 Fig. 1 과 같이 $0.1 \mathrm{~g}$ 의 cotton을 여러가지 농도의 DEAE $\cdot \mathrm{HCl}$ $(0.0-2.0 \mathrm{M})$ 로 처리하였고, 효모 세포의 $\mathrm{OD}_{600}$ 은 2.8 과 6.2로
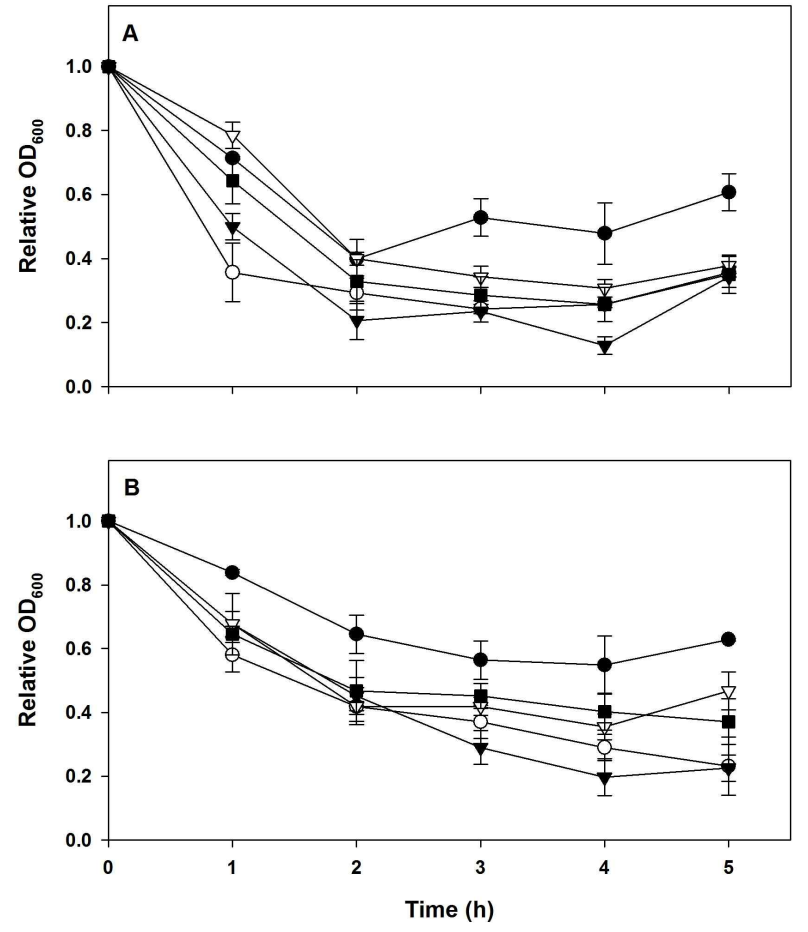

Fig. 2. Immobilizations of yeast cell on DEAE-cotton. DEAE-cotton of $0.1 \mathrm{~g}$ was added, and the initial yeast cell $\mathrm{OD}_{600}$ was (A) 2.8 and (B) 6.2, respectively. DEAE $\mathrm{HCl}$ concentrations were $0.0(\mathbf{O}), 0.25(\bigcirc), 0.5(\nabla), 1.0(\nabla)$, and 2.0 $\mathrm{M}(\boldsymbol{\square})$, respectively. A $10 \mathrm{ml}$ yeast cell suspension was prepared in YPDX medium. Triplicate samples were used for the measurement, and the average and standard deviation were calculated.

조절하였다. 그 결과 Fig. 2 와 같이 cotton을 $\mathrm{DEAE} \cdot \mathrm{HCl}$ 농도 $0.5 \mathrm{M}$ 로 처리하였을 때, 가장 많은 효모가 DEAE-cotton에 흡 착하였다. 그러나 증류수를 사용한 경우 보다는 흡착 정도가 감소한 약 $85-90 \%$ 세포 흡착 결과를 4 시간 후에나 얻을 수 있었다. 이러한 결과는 배지 중 성분이 효모와 경쟁적으로 흡 착에 참여한다는 것을 의미한다고 할 수 있다. 이와 같은 세포 흡착 정도를 증가 시키기 위하여, 이번에는 YPDX 배지에 세포 를 현탁시킨 후, DEAE·HCl로 처리된 cotton의 양을 증가 시 키는 실험을 수행하여 보았다. 이 때 앞의 두 실험의 결과에서 얻은 최적의 $\mathrm{DEAE} \cdot \mathrm{HCl}$ 농도인 $0.5 \mathrm{M}$ 로 cotton을 처리하였고, cotton은 0.1 에서 $0.2,0.4 \mathrm{~g}$ 으로 증가시켰다. 또한 YPDX 배지 에서 효모 세포 농도도 변화를 주었다. 그 결과 Fig. 3 과 같이 효모 세포와 DEAE-cotton의 흡착현상이 관찰 되었으며 Fig. $3 \mathrm{~A}$ 에서는 Fig. 2에서와 같이 완전한 흡착이 일어나지 않았으 나, Fig. 3B와 Fig. 3C 에서는 DEAE-cotton 양의 증가로 효모 세포와 DEAE-cotton간의 완전한 흡착이 관찰되었다. 결론적 으로 여러가지 최적 조건을 유추 할 수 있었으나, DEAE-cotton이 $0.4 \mathrm{~g}$ 이고 효모 세포의 $\mathrm{OD}_{600}$ 이 9.6 이하일 때에 적어도 1 시간 내에 거의 $100 \%$ 흡착이 일어날 수 있음을 확인하였다 

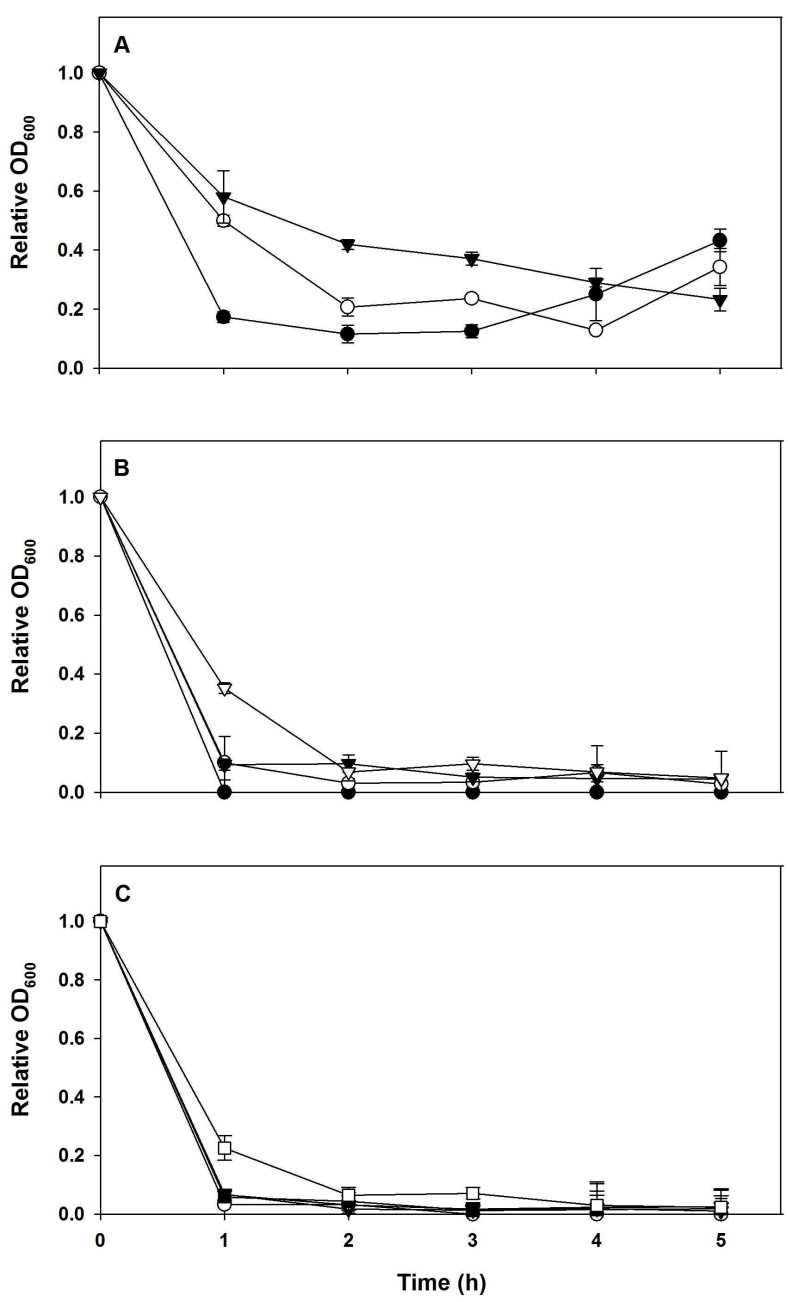

Fig. 3. Immobilizations of yeast cell on DEAE-cotton. DEAE-cottons of (A) 0.1, (B) 0.2, and (C) $0.4 \mathrm{~g}$ were added, and the initial yeast cell $\mathrm{OD}_{600}$ was $1.04(\mathbf{O}), 3.0(\mathrm{O}), 6.0(\boldsymbol{\nabla})$, $8.2(\nabla), 9.6(\square)$, and $12.4(\square)$, respectively. DEAE $\cdot \mathrm{HCl}$ concentrations was $0.5 \mathrm{M}$. A $10 \mathrm{ml}$ yeast cell suspension was prepared in YPDX medium. Triplicate samples were used for the measurement, and the average and standard deviation were calculated.

(Fig. 3C). 그러나 보다 완전한 효모 세포의 흡착을 위하여 $\mathrm{OD}_{600}$ 이 7.6 의 효모를 사용하는 조건을 최적 조건으로 하고, 다음 실험에 적용하였다.

DEAE-cotton의 효모 흡착을 위한 담체로서의 성능을 비교 하기 위하여 시판되고 있는 DEAE-cellulose와 비교 실험을 수 행하였다. Fig. 4 와 같이 먼저 효모 세포를 증류수에 현탁시킨 후, 효모 세포와 DEAE-cellulose와의 흡착을 관찰하였다. 이 때 효모 세포의 $\mathrm{OD}_{600}$ 은 $1.3,2.9,7.1$ 로 조절하였으며 DEAE-cellulose양은 $0.1 \mathrm{~g}$ 에서 $1.0 \mathrm{~g}$ 까지 변화를 주었다. 그 결과 효모 세포의 농도에 따라 차이가 있었으나, Fig. $4 \mathrm{~A}$ 와 Fig. 4B에서는 $0.1 \mathrm{~g}$ 이상의 DEAE-cellulose로 30 분 정도에 모 든 효모 세포가 흡착됨이 관찰되었다. 그리고 Fig. 4 C에서는
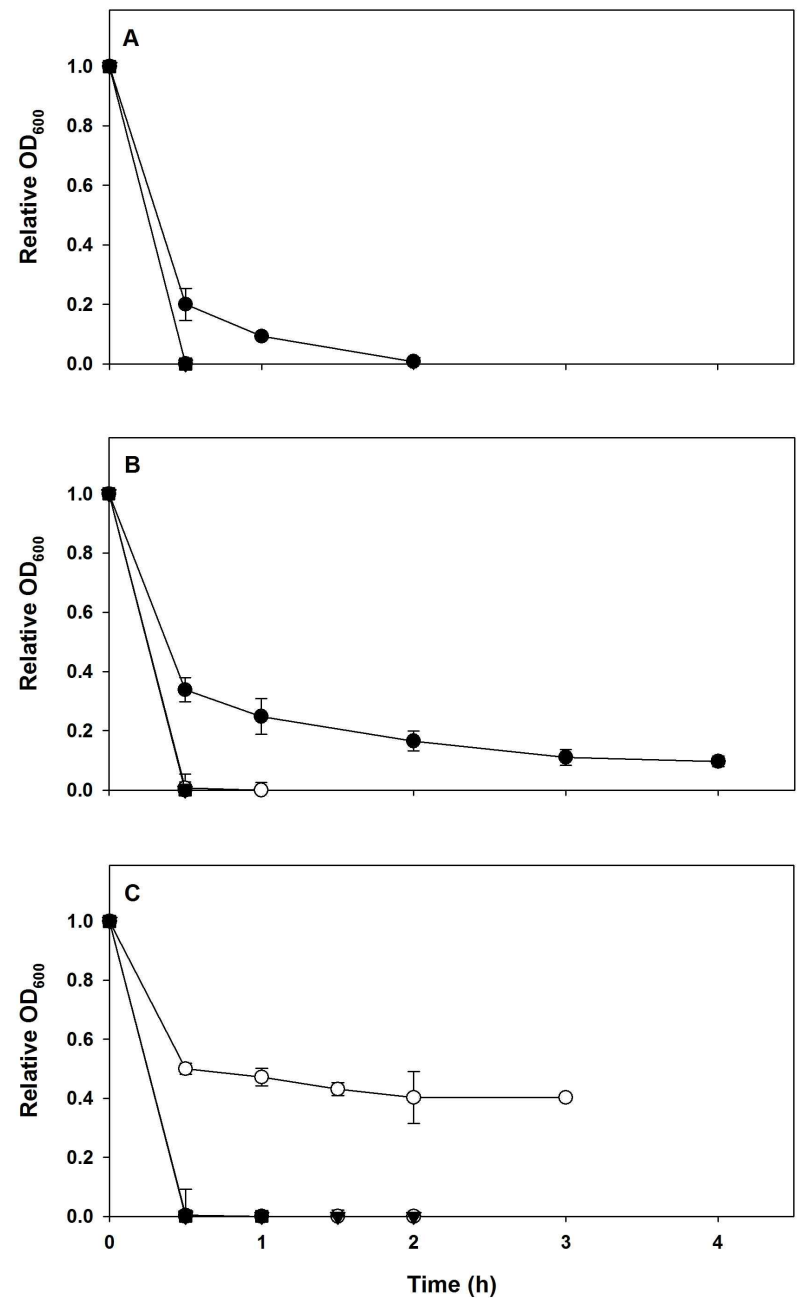

Fig. 4. Immobilizations of yeast cell on DEAE-cellulose. The initial yeast cell $\mathrm{OD}_{600}$ was (A) 1.3, (B) 2.9, and (C) 7.1, respectively. DEAE-cellulose of $0.1(\mathbf{O}), 0.2(\mathrm{O}), 0.5(\mathbf{\nabla})$, $0.7(\nabla)$, and $1.0 \mathrm{~g}(\boldsymbol{\square})$ were added, respectively. A 10 $\mathrm{ml}$ yeast cell suspension was prepared in distilled water. Triplicate samples were used for the measurement, and the average and standard deviation were calculated.

$0.5 \mathrm{~g}$ 이상의 DEAE-cellulose에서 완전한 효모 세포 흡착이 관찰되었다. 한편 Fig. 2 와 Fig. 3 의 DEAE-cotton에서의 실험 에서와 같이 흡착 현상을 $\mathrm{YPDX}$ 배지 내에서 다시 관찰하였다 (Fig. 5). 이 때 효모 세포의 $\mathrm{OD}_{600}$ 은 1.2, 2.9, 7.2로 조절하였고 DEAE-cellulose는 $0.1 \mathrm{~g}$ 에서 $1.0 \mathrm{~g}$ 까지의 양으로 조절하였다. 그 결과 효모 세포가 DEAE-cellulose에 완전히 흡착하는 조건 을 관찰할 수 있었다. 이 때도 전체적인 흡착 정도가 효모 세포 를 증류수에 현탁 시킨 것 보다 떨어졌으며, 그 이유는 위에 언급한 바와 같이 배지 성분 때문인 것으로 추론된다. 이 결과 를 바탕으로 우리는 효모 세포 $\mathrm{OD}_{600} 2.9$ 에 $1.0 \mathrm{~g}$ 의 DEAE-cellulose를 사용 할 경우에 적어도 1 시간 반 내에는 효모 세포가 모두 흡착할 수 있다는 결론을 얻었으며, 이를 다음 실험의 

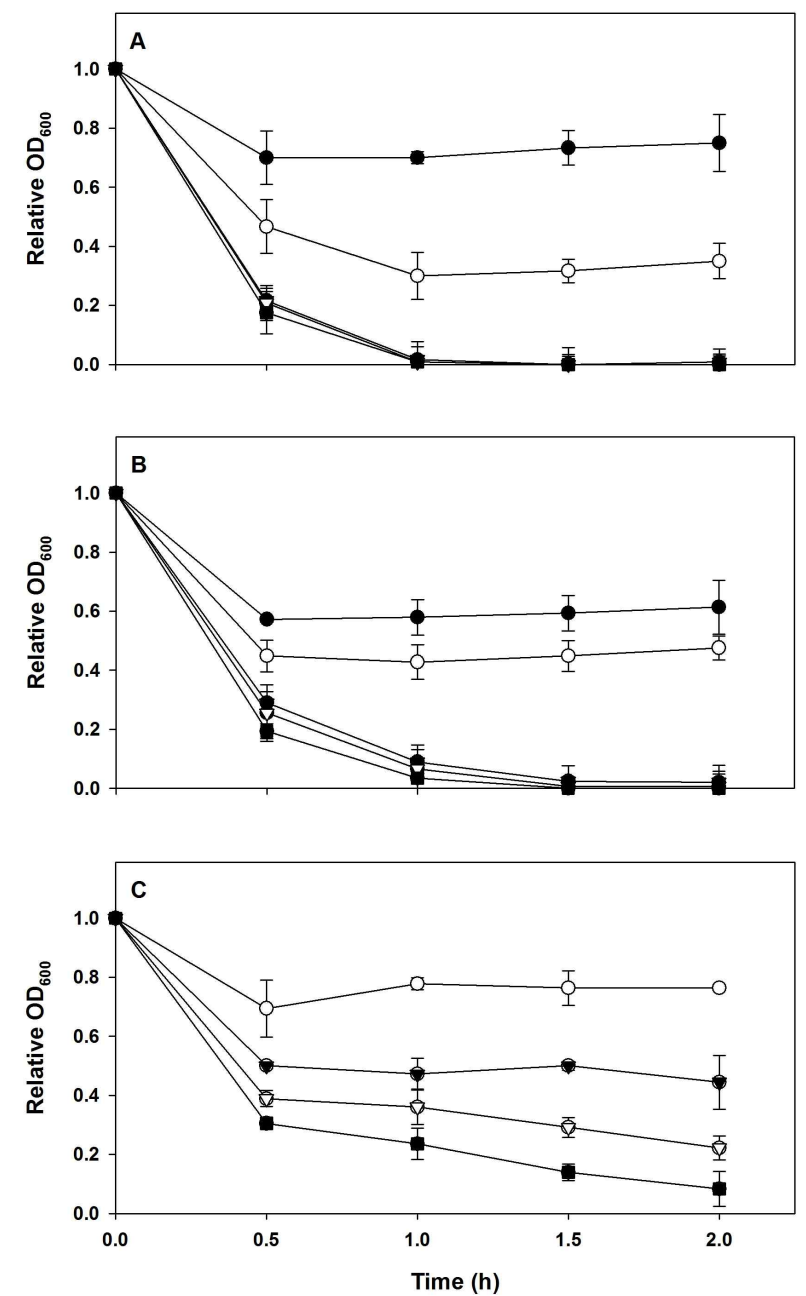

Fig. 5. Immobilizations of yeast cell on DEAE-cellulose. The initial yeast cell $\mathrm{OD}_{600}$ was (A) 1.2, (B) 2.9, and (C) 7.2, respectively. DEAE-cellulose of $0.1(\mathbf{O}), 0.2(\bigcirc), 0.5(\boldsymbol{\nabla})$, $0.7(\nabla)$, and $1.0 \mathrm{~g}(\boldsymbol{\square})$ were used, respectively. A $10 \mathrm{ml}$ yeast cell suspension was prepared in YPDX medium. Triplicate samples were used for the measurement, and the average and standard deviation were calculated.

\section{최적 조건으로 사용하였다.}

한편 최적 흡착 조건에서의 $\mathrm{DEAE}-$ cotton과 $\mathrm{DEAE}-$ cellulose 무게당 $(\mathrm{g})$ 흡착되는 효모 세포의 양을 건조균체량 $(\mathrm{mg})$ 으로 표시하여 보면, DEAE-cotton은 $101.8 \mathrm{mg} / \mathrm{g}, \mathrm{DEAE}$ -cellulose는 $15.5 \mathrm{mg} / \mathrm{g}$ 으로 계산되어진다. 이는 DEAE-cotton 이 DEAE-cellulose에 비해 6배 이상의 효모에 대한 흡착능력 을 가지고 있다는 것을 의미하며, DEAE-cotton이 보다 더 효 율적인 세포고정화 담체로서 사용되어 질 수 있다는 것을 보 여주는 결과라 하겠다. 선행 문헌에서 효모 세포의 흡착량을 살펴보면, woodchip의 경우 $188 \mathrm{mg} / \mathrm{g}$ [13], sorghum bagasse 의 경우 $600 \mathrm{mg} / \mathrm{g}$ [26], corncob의 경우 $22.2 \mathrm{mg} / \mathrm{g}$ [5]으로 보고되고 있다. 그러므로 본 연구에서의 DEAE-contton은 비
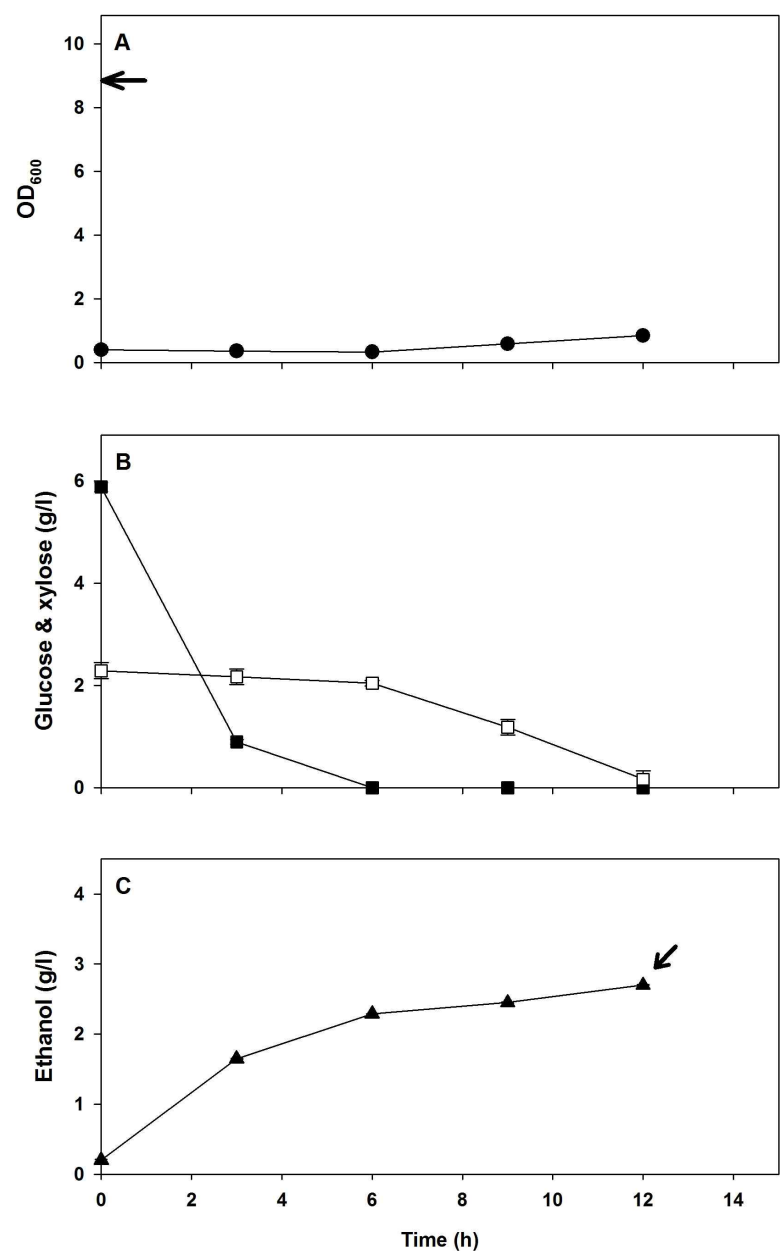

Fig. 6. Flask culture of immobilized $P$. stipitis on DEAE-cotton, in which $0.4 \mathrm{~g}$ DEAE-cotton and initial cell $\mathrm{OD}_{600}$ of 7.6 were added for the immobilization. (A) cell growth, (B) residual glucose $(\square)$ and xylose $(\square)$ concentration, (C) ethanol production. Arrow in panel $\mathrm{A}$ indicates $\mathrm{OD}_{600}$ of seed culture. Cell-immobilized DEAE-cotton arrowed in panel $\mathrm{C}$ was used for the electron microscopy observations in Fig. 8. Triple measurements were conducted, and the average and standard deviation were calculated.

교적 우수한 효모 세포 흡착능력을 가지는 담체임을 알 수 있으며, 이를 이용한 다양한 생물공정 개발에 효과적으로 응 용이 가능할 것으로 판단된다.

\section{DEAE-cotton과 DEAE-cellulose에 흡착 고정화된 $P$.} stipitis를 이용한 flask culture

위와 같이 DEAE-cotton과 DEAE-cellulose에 흡착된 효모 세포를 ethanol 생산에 적용하여, 그 성능을 비교분석하기 위 하여, 육탄당인 glucose와 오탄당인 xylose가 포함된 배지에서 배양실험을 실시하였다. 이 때 효모를 DEAE-cotton과 DEAE-cellulose에 흡착 고정화 시킨 후, 배지가 포함된 flask 

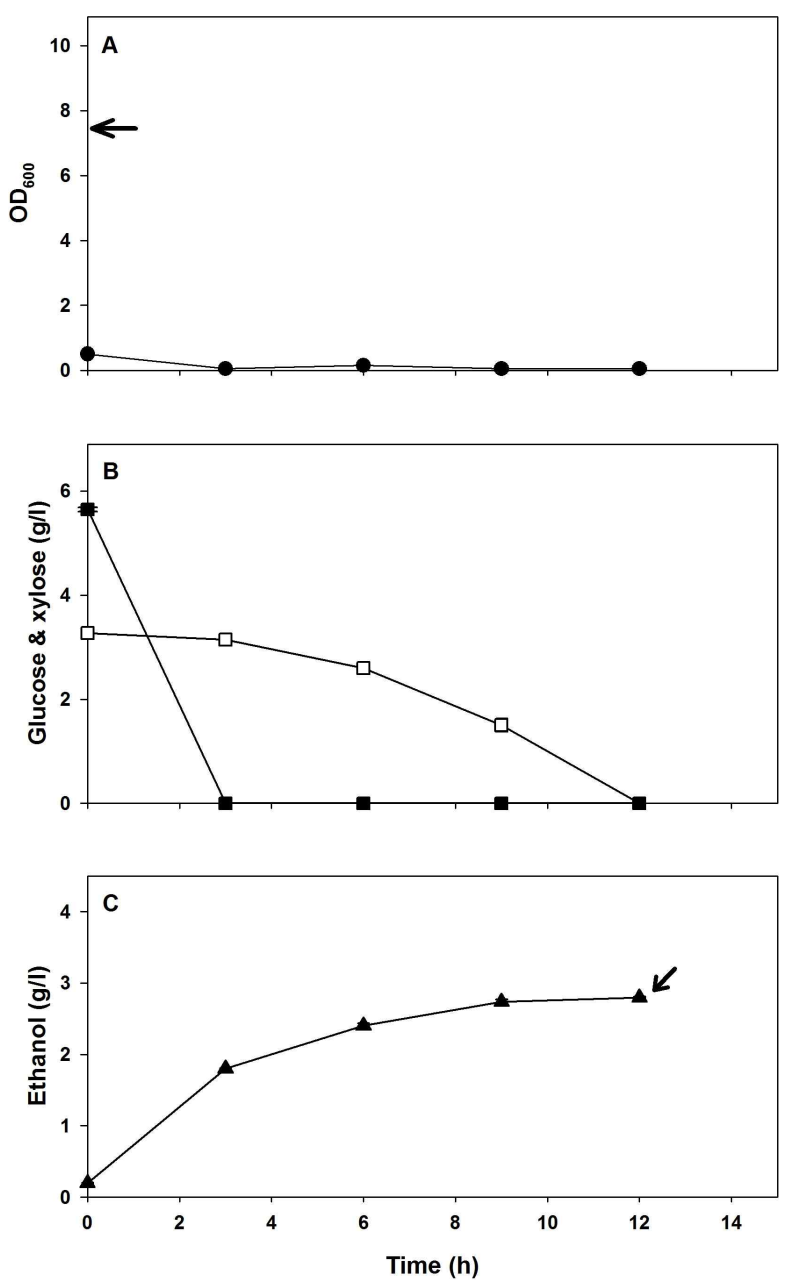

Fig. 7. Flask culture of immobilized P. stipitis. on DEAE-cellulose, in which $2.0 \mathrm{~g}$ DEAE-cellulose and initial cell $\mathrm{OD}_{600}$ of 5.8 were added for the immobilization. (A) cell growth, (B) residual glucose $(\square)$ and xylose $(\square)$ concentration, $(C)$ ethanol production. Arrow in panel A indicates $\mathrm{OD}_{600}$ of seed culture. Cell-immobilized DEAE-cellulose arrowed in panel $\mathrm{C}$ was used for the electron microscopy observations in Fig. 8. Triple measurements were conducted, and the average and standard deviation were calculated.

에 옮겨 배양을 시작하였으며, flask 배지 내의 free cell 농도, glucose와 xylose의 소비, 그리고 ethanol 생성을 관찰하였다 (Fig. 6, 7). Fig. 6A와 Fig. 7A에서 처럼 대부분의 효모 세포가 배양 중에 떨어지지 않고 DEAE-cotton과 DEAE-cellulose에 잘 붙어있는 것이 관찰되었으며, 이 현상은 Fig. $6 \mathrm{~A}$ 와 Fig. $7 \mathrm{~A}$ 에 표시된 seed culture의 $\mathrm{OD}_{600}$ 과 비교하면 더 명확히 알 수 있다. 그리고 glucose와 xylose는 DEAE-cotton과 DEAEcellulose에 붙어 있는 효모 세포에 의하여 Fig. $6 \mathrm{~B}$ 와 Fig. $7 \mathrm{~B}$ 와 같이 glucose가 소모된 후 xylose가 소비되는 현상이 관찰되었 으며, ethanol의 생성 양상을 관찰하여 본 결과 Fig. $6 \mathrm{C}$ 와 Fig.

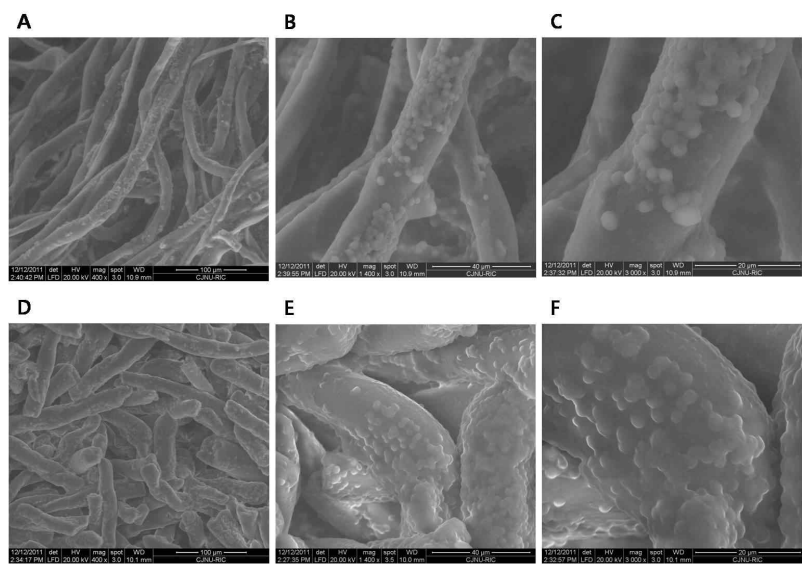

Fig. 8. Electron micrographs of yeast cell-immobilized $(A)(B)(C)$ DEAE-cotton and (D)(E)(F) DEAE-cellulose. Magnification of the electron micrographs: (A)(D) 400x, (B)(E) 1,400x and $(C)(F) 3,000 x$, respectively.

7C처럼 glucose를 완전히 소비한 후 xylose를 소비하면서 ethanol을 생성함을 확인하였다. 이 때 DEAE-cotton을 담체로 한 flask culture에서는 glucose와 xylose의 총합 $8.1 \mathrm{~g} / 1$ 에서 $2.7 \mathrm{~g} / 1$ 의 ethanol이 생산 되었고, DEAE-cellulose의 경우에는 glucose와 xylose의 총합 $8.8 \mathrm{~g} / 1$ 에서 $2.8 \mathrm{~g} / 1$ 의 ethanol이 생산 되었다. 이는 두 단당류의 합에 대한 ethanol 생산 수율로서 각각 약 0.33 과 0.32 이며, 이것은 이론치의 약 62 에서 $64 \%$ 에 해당하는 것이다. 한편 본 연구팀의 선행연구에서 glucose와 xylose가 포함된 가수분해물에서의 ethanol 생산에서 ethanol 수율이 0.297 0.357[25]과 0.368[23] 정도로 관찰되고 있다. 또 한 수율 증진을 위한 미량공기 공급의 조절을 통하여, ethanol 수율 향상도 기대 할 수 있었다[11]. 본 연구에서의 ethanol 수율은 이러한 최적 환경에서 얻어진 것이 아니기 때문에 아 마도 상대적으로 약간 낮은 값을 보이는 것으로 추론된다. 그 래서 ethanol 수율 향상을 위하여서는 ethanol 생산 환경에 대한 최적화 과정이 필요하다고 할 수 있으며, 특히 xylose를 이용하여 ethanol을 생산하기 위한 배양환경 최적화가 선행되 어야 할 것으로 생각된다.

본 연구에서 두 가지 담체 안의 효모 세포의 농도를 직접 측정하지는 못하였지만, Fig. $6 \mathrm{~A}$ 와 Fig. 7A의 결과로 보아서 세포가 잘 흡착되어 자라면서 glucose와 xylose를 소비하고, ethanol을 생산 하였다는 것을 추론 할 수 있었다. 담체에 효모 세포가 흡착된 것을 직접 관찰하기 위하여 Fig. 6과 Fig. 7의 flask culture를 수행 후, 제일 마지막 sampling 후 남아있는 효모 세포가 흡착된 DEAE-cotton과 DEAE-cellulose를 수확 하여 전자현미경으로 Fig. 8 과 같이 관찰하였다. 400 배, 1400 배, 3000배의 배율에서 섬유상 구조의 DEAE-cotton과 DEAE-cellulose 표면에 효모 세포가 흡착되어 있음을 관찰할 수 있었다. 
결론적으로, cotton을 DEAE·HCl로 처리한 DEAE-cotton 은 효모를 이용한 ethanol 생산에 담체로서 사용되어질 수 있 다는 것을 확인 하였으며, 특히 lignocellulosic biomass의 가 수분해물에 포함될 수 있는 glucose와 xylose가 함유된 배지에 서 두 단당류를 이용하여 ethanol 생산이 가능하다는 것을 보 여주었다. 앞으로 실제 lignocellulosic biomass의 가수분해물 을 이용하여 효모 세포가 흡착된 DEAE-cotton을 이용한 bioethanol 생산 공정개발이 기대 되어진다.

\section{감사의 글}

이 연구는 한국해양연구원(Korea Ocean Research \& Development Institute)의 연구비 지원(Project No. PP00740) 에 의하여 이루어졌으며, 이에 심심한 감사를 드립니다.

\section{References}

1. Amory, D. E. and Rouxhet, P. G. 1988. Surface properties of Saccharomyces cerevisiae and Saccharomyces carlbergensis. chemical composition, electrostatic charge and hydrophobicity. Biochim Biophys. Acta 938, 16-70.

2. Bardi, E. P. and Koutinas, A. A. 1994. Immobilization of yeast on delignified cellulosic material for room temperature and low-temperature wine making. J. Agric. Food Chem 42, 221-226.

3. Brányik, T., Silva, D. P., Vicente, A. A., Lehnert, R., Silva, J. B. A. e, Dostálek, P. and Teixeira, J. A. 2006. Continuous immobilized yeast reactor system for complete beer fermentation using spent grains and corncobs as carrier materials. J. Ind Microbiol. Biotechnol. 33, 1010-1018.

4. El-Hilw, Z. H. 1999. Synthesis of cotton-bearing DEAE, carbamoyethyl, carboxyethyl, and poly(acrylamide) graft for utilization in dye removal. J. Polym Sci. 73, 1007-1014.

5. Genisheva, Z., Mussatto, S. I., Oliveira, J. M. and Teixeira, J. A. 2011. Evaluating the potential of wine-making residues and corncobs as support materials for cell immobilization for ethanol production. Ind Crop. Prod 34, 979-985.

6. Hamaker, K., Rau, S.-L., Hendrickson, R., Liu, J., Ladisch, C. M. and Ladisch, M. R. 1999. Rolled stationary phases: Dimensionally structured textile adsorbents for rapid liquid chromatography of proteins. Ind Eng. Chem Res. 38, 865-872.

7. Hebeish, A. and El-Hilw, Z. H. 1998. Preparation of DEAE cotton-g-poly (methacrylic acid) for use as ion exchanger. $J$. Polym Sci. 67, 739-745.

8. Inloes, D. S., Taylor, D. P., Cohen, S. N., Michaels, A. S. and Robertson, C. R. 1983. Ethanol production by Saccharomyces cerevisiae immobilized in hollow-fiber membrane bioreactors. Appl. Environ. Microbiol. 46, 264-278.

9. Kumar, S., Singh, S. P., Mishra, I. M. and Adhikari, D. K. 2011. Continuous ethanol production by Kluyveromyces sp. IIPE453 immobilized on bagasse chips in packed bed reactor. J. Petrol. Technol. Altern. Fuels 2, 1-6.
10. Lee, C. W. and Chang, H. N. 1987. Kinetics of ethanol fermentations in membrane cell recycle fermentors. Biotechnol. Bioeng. 29, 1105-1112.

11. Lee, S. E., Kim, H. J., Choi, W. Y., Kang, D. H., Lee, H.-Y. and Jung, K.-H. 2011. Optimal surface aeration rate for bioethanol production from the hydrolysate of seaweed Sargassum sagamianum using Pichia stipitis. KSBB J. 26, 311-316.

12. Margaritis, A. and Merchant, F. J. A. 1984. Advances in ethanol production using immobilized cell systems. CRC Crit. Rev. Biotechnol. 1, 339-393.

13. Moo-Young, M., Lamptey, J. and Robinson, C. W. 1980. Immobilization of yeast cells on various supports for ethanol production. Biotechnol. Lett. 2, 541-548.

14. Nagashima, M., Azuma, M., Noguchi, S., Inuzuka, K. and Samejima, H. 1984. Continuous ethanol fermentation using immobilized yeast cells. Biotechnol. Bioeng. 26, 992-997.

15. Roberts, E. J. and Rowland, S. P. 1973. Removal of mercury from aqueous solutions by nitrogen-containing chemically modified cotton. Environ. Sci. Technol. 7, 552-555.

16. Robyt, J. F. and Mukerjea, R. 1994. Separation and quantitative determination of nanogram quantities of maltodextrins and isomaltodextrins by thin-layer chromatography. Carbohydr. Res. 251, 187-202.

17. Silva, D. P., Brányik, T., Dragone, G., Vicente, A. A., Teixeira, J. A. and Silva, J. B. A. e. 2008. High gravity batch and continuous processes for beer production: Evaluation of fermentation performance and beer quality. Chem Pap. 62, 34-41.

18. Singh, N. L., Srivastava, P. and Mishra, P. K. 2009. Studies on ethanol production using immobilized cells of Kluyveromyces thermotolerans in a packed bed reactor. J. Sci. Ind Res. 68, 617-623.

19. Sungur, S. and Babaoğlu, S. 2005. Synthesis of a new cellulose ion exchanger and use for the separation of heavy metals in aqueous solutions. Sep. Sci. Technol. 40, 2067-2078.

20. Verbelen, P. J., De Schutter, D. P., Delvaux, F., Verstrepen, K. J. and Delvaux, F. R. 2006. Immobilized yeast cell systems for continuous fermentation applications. Biotechnol. Lett. 28, 1515-1525.

21. Wada, M., Kato, J. and Chibata, I. 1980. Continuous production of ethanol using immobilized growing yeast cells. Appl. Microbiol. Biotechnol. 10, 275-287.

22. Williams, D. and Munnecke, D. M. 1981. The production of ethanol by immobilized yeast cells. Biotechnol. Bioeng. 23, 1813-1825.

23. Yeon, J.-H., Lee, S.-E., Choi, W. Y., Choi, W. S., Kim, I. C., Lee, H.-Y. and Jung, K.-H. 2011. Bioethanol production from the hydrolysate of rape stem in a surface-aerated fermentor. J. Microbiol. Biotechnol. 21, 109-114.

24. Yeon, J.-H., Lee, S.-E., Choi, W. Y., Kang, D. H., Lee, H.-Y. and Jung, K.-H. 2011. Repeated-batch operation of surfaceaerated fermentor for bioethanol production from the hydrolysate of seaweed Sargassum sagamianum J. Microbiol. Biotechnol. 21, 323-331.

25. Yeon, J.-H., Seo, H.-B., Oh, S. H., Choi, W. S., Kang, D. H., 
Lee, H.-Y. and Jung, K.-H. 2010. Bioethanol production from hydrolysate of seaweed Sargassum sagamianum KSBB J. 25, 283-288.
26. Yu, J., Zhang, X. and Tan, T. 2007. An novel immobilization method of Saccharomyces cerevisiae to sorghum bagasse for ethanol production. J. Biotechnol. 129, 415-420.

초록 : 에탄올 생산을 위한 효모 Pichia stipitis의 고정화

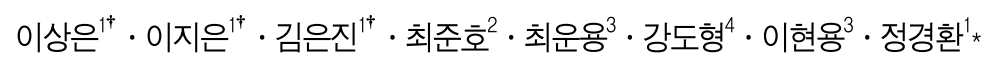

('훙주대학교 생명공학과, ${ }^{2}$ 원광대학교 식품생명공학과, ${ }^{3}$ 강원대학교 생물소재공학전공, ${ }^{4}$ 한국해양연구원)

Cotton을 효모 세포(Pichia stipitis)의 고정화 담체로 사용하기 위하여 2-(diethylamino)ethyl chloride hydrochloride (DEAE·HCl)로 derivatization 시켰다. $0.5 \mathrm{M} \mathrm{DEAE} \cdot \mathrm{HCl}$ 로 처리하였을 때, 효모 세포가 완전히 흡착하였 으며, 이것은 DEAE-cotton g 당 $101.8 \mathrm{mg}$ 의 효모 세포가 흡착하는 것이고, DEAE-cellulose에 효모 세포가 흡착하 는 양의 약 6배 이상인 것으로 확인되었다. DEAE-cotton을 이용하여 효모 세포를 고정화하고, 이것을 ethanol 생산에 이용하였을 경우, glucose와 xylose가 포함된 배지에서 단당류에 대한 ethanol 수율로 0.33 정도로 ethanol 을 생산 할 수 있다는 것을 실험적으로 확인하였다. 이를 이용하여 lignocellulosic bomass의 가수분해물로부터 bioethanol 생산에 이용될 수 있을 것으로 기대되어진다. DEAE-cotton에서 얻어진 결과는 DEAE-cellulose에서 같은 실험을 실시하여 서로 비교 분석하였다. 